\title{
A review of bush dog Speothos venaticus (Lund, 1842) (Carnivora, Canidae) occurrences in Paraná state, subtropical Brazil
}

\author{
L. M. Tiepolo ${ }^{*}$, J. Quadros ${ }^{a}$ and M. R. P. L. Pitman \\ ${ }^{\mathrm{a}}$ Graduate Program in Sustainable Territorial Development, Universidade Federal do Paraná - UFPR, \\ Rua Jaguariaíva, 512, CEP 83260-000, Matinhos, PR, Brazil \\ ${ }^{b}$ Nicholas School of the Environment, Center for Tropical Conservation, \\ Duke University, Box 90328, Durham, NC 27708, United States \\ *e-mail: liliani@ufpr.br
}

Received: October 2, 2014 - Accepted: February 2, 2015 - Distributed: May 31, 2016

(With 1 figure)

\begin{abstract}
We report six new occurrence records of the bush dog Speothos venaticus, a widely distributed South American carnivore that is threatened with extinction. These records are accompanied by notes on the places where the records were made, such as vegetation type, date and information about the protection of areas. The records, obtained over the last 17 years in Paraná state, southern Brazil, offer an improved understanding of the species geographic range and the threats it faces and can enable better assessments of the conservation status of the species in southern Brazil.
\end{abstract}

Keywords: Atlantic Forest, bush-dog, Speothos venaticus, subtropical Brazil, threatened species.

\section{Revisão dos registros de ocorrência do cachorro-do-mato-vinagre Speothos venaticus (Lund, 1842) (Carnivora, Canidae), no Estado do Paraná, Brasil Subtropical}

\section{Resumo}

Apresentamos seis novos registros de ocorrência do cachorro-do-mato-vinagre Speothos venaticus, um carnívoro sul Americano de ampla distribuição geográfica, porém ameaçado de extinção. Os registros são acompanhados de notas sobre os locais onde foram obtidos, tais como: tipo de vegetação, datas e informações sobre a proteção das áreas. Os registros, obtidos ao longo dos últimos 17 anos no Estado do Paraná, na região sul do Brasil, oferecem uma maior compreensão acerca da distribuição geográfica e das ameaças que a espécie enfrenta, permitindo melhores avaliações sobre o status de conservação desta espécie no sul do Brasil.

Palavras-chave: Floresta Atlântica, cachorro-do-mato-vinagre, Speothos venaticus, Brasil subtropical, espécie ameaçada.

\section{Introduction}

The bush dog, Speothos venaticus (Lund, 1842), is a small canid widely distributed in South America. It ranges from Panama (Central America) in the north to northeastern Argentina and Paraguay in the south; and also occurs in Colombia, Venezuela, the Guianas, Brazil, and eastern Bolivia and Peru (Alderton, 1994). Its unique features give it the most distinctive appearance of all canids: small size, elongated body, small eyes, short snout, short tail, short legs, and small and rounded ears, in addition to gregarious and diurnal behavior (Beisiegel and Zuercher, 2005; Busto and Pérez, 1998; Alderton, 1994; Sheldon, 1992).

Considered naturally rare and difficult to see within its geographic range (Emmons and Feer, 1997; Beisiegel and Zuercher, 2005), the species has been recorded occasionally in South America, as summarized by Defler (1986) for Colombia; Beccaceci (1994) for Paraguay;
Strahl et al. (1992) for Venezuela; Barnett et al. (2001) for Guyana; and Aquino and Puertas (1997) for the Peruvian Amazon. DeMatteo and Loiselle (2008) reviewed what was known about the species' distribution in order to assess its overlap with protected areas and to recommend strategies for its conservation. In Brazil the species has been recorded at a few sites in Goiás by Silveira et al. (1998); in the Amazonian region by Silva-Júnior and Soares (1999); in the Pantanal by Rodrigues et al. (2002); in the Atlantic Forest of São Paulo state by Beisiegel and Ades (2004); in Pará, Tocantins, and Maranhão by Oliveira (2009); in Mato Grosso by Michalski (2010); in Mato Grosso do Sul by Teribele et al. (2012); and in Paraná by Fusco and Ingberman (2012).

Difficulties to obtain information on the species' ecology, distribution and behavior has generated significant 
interest in the species and led to research focused on its conservation. For example, Peres (1991) reported observations on bush dog hunting behavior in Amazonia. Busto and Pérez (1998) reported new insights into the species' behavior in the wild, based on observations of five individuals captured in the headwaters of the Acaray River (Paraguay) and raised in captivity at the Itaipu Wildlife Research Center. They reported that the animals, two parents and three pups, were captured in dense forest from a den constructed under the trunk of a canafistula tree (Peltophorum dubium). The den had a striking system of subterranean rooms with multiple exits that were small and well-concealed by vegetation. Other recent studies have focused on the natural history of the species in the Atlantic Forest (Beisiegel, 1999; Beisiegel and Ades, 2002); on methods of attracting bush dogs for research in Paraguay's Mbaracayú Reserve (DeMatteo et al., 2004); on radio-telemetry with captive animals (DeMatteo and Kochanny, 2004); on diet and habitat in eastern Paraguay (Zuercher et al., 2005); and on home range, activity patterns, and habitat selection (Lima et al., 2012). A review of existing information on bush dogs carried out by canid specialists was recently compiled by DeMatteo (2008).

The red list of globally threatened species classified Speothos venaticus as Vulnerable in 1996, but demoted the species to Near Threatened in 2008. There was no explanation for the change, which was unexpected given that the species' population trend is declining and the threats it faces increasing (IUCN, 2012a, b). S. venaticus is listed in Appendix I of the Convention on International Trade in Endangered Species of Wild Fauna and Flora (CITES), which protects the animal species most severely threatened by hunting at the international level. It is worth noting that just one other canid (gray wolf, Canis lupus) is listed on CITES Appendix I, which protects several other notoriously threatened species, including giant panda (Ailuropoda melanoleuca), red panda (Ailurus fulgens), elephants (Elephas maximus and Loxodonta africana), gorillas (Gorilla spp.), chimpanzees (Pan spp.), and Tasmanian wolf (Thylacinus cynocephalus), which is possibly extinct (CITES, 2012).

In Brazil, state-level red lists suggest a more critical status for bush dogs. The species is considered likely extinct in Minas Gerais (Machado et al., 2005), despite a recent record in the state after 170 years without a sighting (Braga, 2012). In Rio de Janeiro and São Paulo bush dogs are classified as Critically Endangered (Bergallo et al., 2000; São Paulo, 1998), while in Paraná (Braga et al., 2010) and Rio Grande do Sul (Fontana et al., 2003) they are considered Vulnerable, in line with the national red list status (Chiarello et al., 2008). The Paraná red list offers no information regarding the species apart from noting that "[...] given the limited number of confirmed records in the state, maintaining the national-level classification is recommended [...]" (Braga et al., 2010, p. 71).

In order to inform more detailed analyses of the species' geographical distribution and the design of effective conservation measures, we compiled records and information on occurrence localities over the last 17 years in Paraná state, subtropical Brazil. Based on this new information, we argue that an updated threat status is needed for Speothos venaticus in Paraná state.

\section{Methods}

Information on the species was compiled from several field studies over the last two decades in Paraná state, via direct observations of the species and its sign in the wild. Field observations were complemented with searches of collection records in museums and the scientific literature, and via interviews with trusted sources who are familiar with the species and have recorded it recently.

Only records from Paraná state (southern Brazil) over the last 20 years were included in the study. Each record included geographical coordinates (degrees-minutes-seconds) and the most complete possible details, such as time of day, site characteristics, number of individuals, and other complementary information. Vegetation at the occurrence localities was classified following the system of Veloso et al. (1991). Threat categories discussed here are those used by the International Union for the Conservation of Nature and Natural Resources (IUCN, 2012a, b).

ArcView10 software was used to map the records onto a layer of the Phytogeographic Map of Paraná (1989/1990) obtained from Maack/ITCG/IBGE.

\section{Results and Discussion}

The current literature contains very little information on bush dog occurrence in southern Brazil (e.g., Beisiegel and Zuercher, 2005; DeMatteo and Loiselle, 2008). Distribution maps of the species are based on confirmed occurrence records, more generalized estimated range maps like those of Eisenberg (1989), Redford and Eisenberg (1992, 1999), and Emmons and Feer (1997), and a compilation of interviews with researchers working throughout the area where bush dogs are likely to occur. At the continental scale, the maps with the highest resolution are those of Beisiegel and Zuercher (2005), Zuercher et al. (2004), and DeMatteo \& Loiselle (2008). At the regional level, Oliveira (2009) has provided precise occurrence records for Speothos venaticus in northern Brazil, and Michalski (2010) has done the same for some records in Mato Grosso state.

Despite this striking lack of information regarding the species' occurrence in southern Brazil, the first documented record in the region was made in 1911 by the naturalist Hermann von Iheringi, who described the species Speothos wingei with the type locality of "Santa Catarina". Cabrera (1958, 1960) did not accept Speothos wingei as valid, considering it one of two subspecies: Speothos venaticus venaticus and Speothos venaticus wingei. Wilson and Reeder (2005) subsequently treated wingei as one of three subspecies: $S$. venaticus venaticus, $S$. venaticus panamensis, and $S$. venaticus wingei. Vieira (1946) attributed Icticyon venaticus, the specimen von Ihering used to describe the new species, to the locality Colônia Hansa in Santa Catarina. This specimen and one other from the same locality are 
deposited in the mammal collection of the Museum of Zoology of the University of São Paulo, under Nos 2864 and 2902, respectively. Vieira (1946, p. 157) described the fur of the Speothos wingei holotype as "[...] almost albino, with a very light yellowish-brown color on nearly the entire body, except the legs and tail.". According to the author, the other specimen from the same locality was identical to a specimen he examined from São João da Boa Vista, São Paulo state.

Eighty-five years after the first record was made in Santa Catarina, Cimardi (1996) reported a second: near Sassafrás Biological Reserve, in the municipality of Mafra, in the northern portion of the state. Few additional details were provided.

We compiled eight records of bush dog in Paraná state over the last 17 years, as described below and illustrated in Figure 1. The geographic coordinates of these records are given in Table 1 and plotted in the map in Figure 1. These records represent a marked increase in the number of confirmed occurrences of the species in southern Brazil.

(1) Iguaçu National Park, Foz do Iguaçu: a record made by Peter Crawshaw in 1995, during his studies of Leopardus pardalis and Panthera onca ecology in Foz do Iguaçu and in Argentina (Crawshaw, 1995). Reports by local residents regarding the species' presence were confirmed via an analysis of the bile-acids in scats, which matched the standard profile for the species (Leite Pitman, pers. comm.). The area is protected by Iguaçu National Park, most of which is covered by Seasonal Semideciduous Forest. The park measures 185,262 ha and is contiguous with the 67,720 ha Argentinian park of the same name.

(2) Serra dos Castelhanos, Guaratuba: a record made by biologists Liliani Marília Tiepolo and Alexandre Lorenzetto in 1999 between the Atlantic Forest mountain range and coastal lowlands, via interviews with a local resident. The resident described the species and reported having killed two "cachorro-pitoco" that attacked the chickens in his property. Vegetation in the area is Dense Montane, Submontane, and Lowland Ombrophilous Forest. The site is inside the Guaratuba Environmental Protection Area, a 199,596 ha sustainable use protected area, and in the immediate vicinity of Saint-Hilaire/Lange National Park, a 25,000 ha strictly protected area.

(3) Estrada do Cerne (Cerne Road), Castro: this record is based on a stuffed specimen deposited in the Museum of Zoology of Ponta Grossa State University.

Table 1. Occurrence record localities of Speothos venaticus in Paraná state.

\begin{tabular}{cccc}
\hline $\mathbf{N}$ & Locality & Coordinates & Record type \\
\hline 1 & Iguaçu National Park, Foz do Iguaçu & $25^{\circ} 04^{\prime} \mathrm{S} 53^{\circ} 58^{\prime} \mathrm{W}$ & Bile analysis \\
2 & Serra dos Castelhanos, Guaratuba & $25^{\circ} 47^{\prime} \mathrm{S} 48^{\circ} 54^{\prime} \mathrm{W}$ & Interview \\
3 & Cerne Road, Castro & $24^{\circ} 57^{\prime} \mathrm{S} 49^{\circ} 48^{\prime} \mathrm{W}$ & UEPG Zoology Laboratory \\
4 & Rio Cachoeira Nature Reserve, Antonina & $25^{\circ} 19^{\prime} \mathrm{S} 45^{\circ} 42^{\prime} \mathrm{W}$ & Tracks \\
5 & Nova Fronteira Farm, Guaraqueçaba & $25^{\circ} 12^{\prime} \mathrm{S} 48^{\circ} 15^{\prime} \mathrm{W}$ & Visual \\
6 & Serra do Itaqui Nature Reserve, Guaraqueçaba & $25^{\circ} 28^{\prime} \mathrm{S} 48^{\circ} 47^{\prime} \mathrm{W}$ & Fusco and Ingberman (2012) \\
7 & Morro da Mina Nature Reserve, Antonina & $25^{\circ} 21^{\prime} \mathrm{S} 48^{\circ} 46^{\prime} \mathrm{W}$ & Fusco and Ingberman (2012) \\
8 & Municipality of Sengés & $24^{\circ} 19^{\prime} \mathrm{S} 49^{\circ} 22^{\prime} \mathrm{W}$ & Visual \\
\hline
\end{tabular}

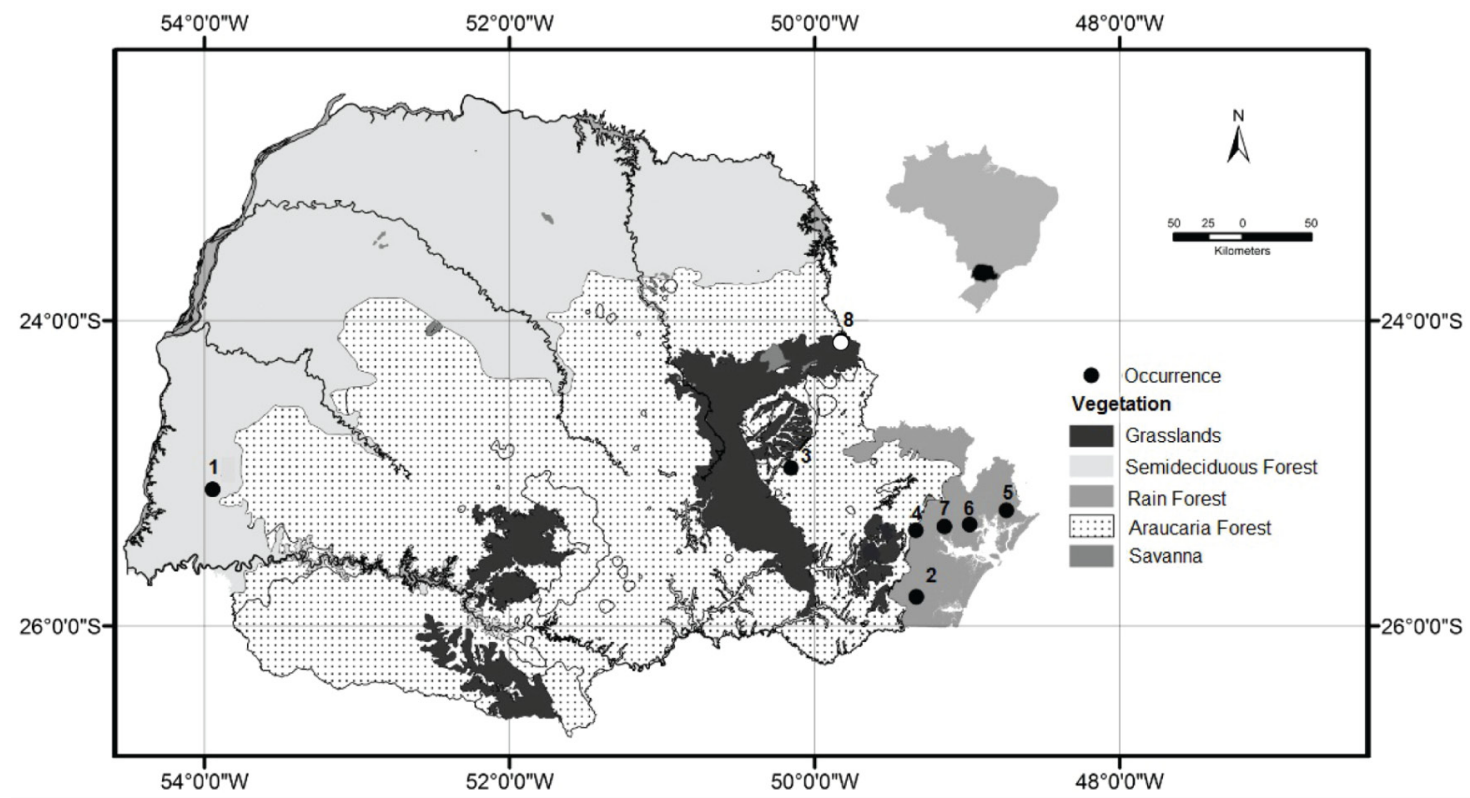

Figure 1. Map of vegetation in Paraná state, southern Brazil, showing the occurrence record localities of Speothos venaticus. 
The specimen was identified by Liliani Marilia Tiepolo in 2003 and the record published by Zanon et al. (2003). According to the authors, the animal was killed by a hunter. In the 80's on Estrada do Cerne, between Castro and the town of Abapan, collected by workers of the Lands and Cartography Institute (now ITCG), and donated to Ponta Grossa State University, where it was stuffed and used as a teaching aid. Vegetation in the region is a mosaic of Steppes (natural fields), soybean and Pinus sp. plantations, pastures, and Mixed Ombrophilous Forest (forest with Araucaria angustifolia).

(4) Rio Cachoeira Nature Reserve, Antonina: tracks of the species were observed by Juliana Quadros in 2005 (on the Arapongas Trail) and 2007 (on the Ferro Trail) during field work in the reserve. Measuring 8,600 ha, the reserve protects Atlantic Forest in a variety of successional stages, including Alluvial Ombrophilous Forest, Dense Submontane Ombrophilous Forest, Dense Lowland Ombrophilous Forest, River and Ocean-influenced Pioneer Formations, as well as disturbed areas where former pasture is returning to forest. Fusco and Ingberman (2012) also recorded bush dog tracks at this locality.

(5) Nova Fronteira Farm, Guaraqueçaba: three individuals were seen by ornithologists Fernando Costa Straube and Leonardo Deconto on 19 October 2011, at approximately 9:45 AM on the secondary road leading to Salto Morato Nature Reserve. The observers were able to observe the animals from a distance of 8-10 m and confirmed all of the characteristic features of the species: small size, short legs and tail, broad head, and small eyes. They also emphasized the rusty reddish color of the back of the animals' necks. The locality is at $22 \mathrm{~m}$ elevation and within the Nova Fronteira Farm (a privately owned ranch), approximately $1.6 \mathrm{Km}$ from the Guaraqueçaba River and 3.0 Km from the southeastern border of Salto Morato Nature Reserve. The area is forested, with pioneer tree species along the forest edges and mature forest in its center. Near this site is the 2,340-ha Salto Morato Nature Reserve, which forms part of the 282,444-ha Guaraqueçaba Environmental Protection Area. Vegetation at Salto Morato consists of Alluvial Ombrophilous Forest, Dense Montane and Submontane Ombrophilous Forest, and River-influenced Pioneer Formations.

(6) Serra do Itaqui Nature Reserve: two records of adult individuals were obtained with a camera trap on two consecutive days in August 2011 by Fusco and Ingberman (2012). The reserve covers 6,650 ha, ranges in elevation from 0 to $800 \mathrm{~m}$, and is covered in Dense Ombrophilous Forest. The reserve forms part of a block of continuous forest within the Guaraqueçaba Environmental Protection Area, a sustainable use protected area comprising private properties and public and private strictly protected areas.

(7) Morro da Mina Nature Reserve: two adults were photographed with a camera trap in October 2011 by Fusco and Ingberman (2012). The 3,300 ha reserve is located in the town of Antonina, in coastal Paraná, and covered in Dense Ombrophilous Forest.
(8) Sengés: two adult individuals were observed by geologist Márcio Kazubek at approximately 12:30, February 2011. The animals were on an infrequently used road in well-preserved gallery forest with Araucaria angustifolia trees, interspersed with natural fields and steep escarpments dominated by Pinus sp. plantations. The observer described the two animals as small with stubby tails, stocky bodies, large heads, dark brown coloration in the posterior portion of the body, and more reddish coloration on the head. The site is close to the old Fazenda Morungava, and contains a mosaic of soybean plantations, pastures, Pinus sp. plantations, and natural vegetation that remains connected to some degree. Human population density in the area is low, due to the rugged terrain of the Devonian Escarpment. The observer also mentioned that several species of mammals were commonly observed in the region, and emphasized that the two individuals he saw were not tayras (Eira barbara), which can be confused with bush dogs because of their similar size and coloration.

One other putative record of $S$. venaticus in Paraná was discarded after a review of the information. The report was based on two bush dogs, male and female, that arrived at the Curitiba Zoo between 1986 and 1987. The animals were found in the Boqueirão neighborhood of the city (where the zoo is located), after children were reported throwing rocks at them. The person who rescued the animals (Francisco Cominese), however, revealed a detail that was not in the original record: the animals were inside a broken box that had been discarded in the street. One of the animals was outside the box and being harassed by the children, while the other was inside. The box was full of old scat, which suggests that the animals had traveled a long distance in it. Both animals were tame and allowed themselves to be petted, which is typical of animals raised in captivity. One of these individuals is now deposited in the Capão da Imbuia Natural History Museum. Given the uncertainty regarding the original locality, the record was excluded from our database.

These records increase the number of localities where $S$. venaticus have been recorded in Paraná State from four (Mangini et al., 2009; Fusco and Ingberman, 2012) to eight. They also show that the species is occasional in Paraná in both forested and non-forested areas (i.e., open areas interspersed with croplands, Cerrado, and Araucaria forest), as illustrated by the records from Castro, Ponta Grossa, and Sengés. Likewise, these records show that $S$. venaticus travels during the day through disturbed areas close to densely populated towns and that it is hunted, as illustrated by the records from Serra dos Castelhanos and the Cerne Road.

Of the records described in this paper, four are in protected areas or in the vicinity of protected areas. This reflects the important role these areas play in the conservation of threatened fauna. A high priority for research is now to determine the population densities of bush dogs at these localities.

Speothos venaticus has been classified as threatened on the Paraná state red list since it was first published in 
1995. In the first edition of the red list Margarido (1995) considered the species Endangered, but noted the lack of official occurrence records in Paraná and cited the state of Santa Catarina as the southernmost extent of its range. In the second edition of the red list, Margarido and Braga (2004) classified the species as Critically Endangered, based on the only two records known at that time (Crawshaw, 1995; Zanon et al., 2003). In light of the scarcity of state-level records, in the list of Braga et al. (2010) the threat category was changed to Vulnerable, in line with the species' status at the national level. Given the new records described here, the infrequency of bush dog sightings, the degree of fragmentation and degradation of natural landscapes in Paraná, the growth in industrial monoculture agriculture in the state and the recent changes imposed to the Forest Code becoming less restrictive to deforestation, it appears that the species merits listing as Critically Endangered in future assessments of its conservation status in Paraná.

\section{Acknowledgements}

We are grateful to the researchers who made this study possible by providing bush dog observations, especially Fernando Costa Straube, Leonardo Deconto (Hori Consultoria), and Márcio Kazubek. We thank the managers of the Rio Cachoeira Nature Reserve for their support during mammal surveys there, Luiz Fernando Schwartzman for making the map and to Nigel Pitman for the valuable work of translation. This study was funded by Brazil's National Council for Scientific and Technological Development (CNPq grant n ${ }^{\circ}$ 562357/2010-6).

\section{References}

ALDERTON, D., 1994. Foxes, wolves and wild dogs of the world. London: Blandford Press.

AQUINO, R. and PUERTAS, P., 1997. Observations of Speothos venaticus (Canidae: Carnivora) in its natural habitat in Peruvian Amazonia. Zeitschrift fur Saugetierkunde, vol. 62, pp. 117-118.

BARNETT, A., SHAPLEY, R. and ENGSTROM, M., 2001. Records of the bushdog, Speothos venaticus (Lund, 1842) from Guyana. Mammalia, vol. 65, no. 2, pp. 232-237.

BECCACECI, M.D., 1994. Bush dogs in Paraguay. Canid News, no. 2 , pp. 17.

BEISIEGEL, B.M. and ADES, C., 2002. The behavior of the bush dog (Speothos venaticus Lund, 1842) in the field: a review. Revista de Etologia, no. 4, pp. 17-23.

BEISIEGEL, B.M. and ADES, C., 2004. The bush dog Speothos venaticus (Lund, 1842) at Parque Estadual Carlos Botelho, Southeastern Brazil. Mammalia, vol. 68, no. 1, pp. 65-68. http:// dx.doi.org/10.1515/mamm.2004.009.

BEISIEGEL, B.M. and ZUERCHER, G.L., 2005. Speothos venaticus. Mammalian Species, vol. 783, pp. 1-6. http://dx.doi. org/10.1644/783.1.

BEISIEGEL, B.M., 1999. Contribuição ao estudo da história natural do cachorro-do-mato, Cerdocyon thous, e do cachorro- vinagre, Speothos venaticus. São Paulo: Universidade de São Paulo, 100 p. PhD Thesis in Psychology.

BERGALLO, H.G., ROCHA, C.F.D., ALVES, M.A.S. and VAN SLUYS, M., 2000. A fauna ameaçada de extinção do Estado do Rio de Janeiro. Rio de Janeiro: Eduerj. 166 p.

BRAGA, E., 2012 [viewed 19 January 2014]. Cachorro-vinagre dá as caras em Minas depois de 170 anos. Jornal Hoje em Dia [online]. Available from: http://www.hojeemdia.com.br/minas/ cachorro-vinagre-da-as-caras-em-minas-depois-de-170-anos-1.48009

BRAGA, F.G., MARGARIDO, T.C.C., MIRANDA, J.M.D., AGUIAR, L.M., MORO-RIOS, R.F., PEREIRA, J.E.D., BILSKI, D.R., DOMIT, C., VOGLIOTTI, A., INGBERMAN, B., FUSCOCOSTA, R., TIEPOLO, L.M., PASSOS, F.C., RINALDI, A.R., ABREU, K.C., BARNARDI, I.P., DUARTE, J.M.B., MANGINI, P.R., ROSA, L., SASAKI, G., LONDOÑO, M.C.R., MOREIRA, N., BRITTO, M.M. and ROCHA, V., 2010. Parte IV: outros mamíferos. In: Instituto Ambiental do Paraná - IAP. Mamíferos ameaçados do Paraná. Curitiba: IAP, pp. 62-93.

BUSTO, J.V.H. and PÉREZ, N., 1998. Estudios del Jagua Yvyguy, Speothos venaticus, en el Centro de Investigación de Animales Silvestres de Itaipú (CIASI). Biota Itaipu Binacional, no. 8, pp. 1-35.

CABRERA, A., 1958. Catálogo de los mamíferos de América del Sur. v. 1. Revista do Museo Argentino de Ciências Naturales Bernardino Rivadavia: Zoologia, vol. 4, no. 1, pp. 1-307.

CABRERA, A., 1960. Catálogo de los mamíferos de América del Sur. Revista del Museo Argentino de Ciências Naturales Bernardino Rivadavia: Zoologia, vol. 4, no. 2, pp. 309-732.

CHIARELLO, A.G., AGUIAR, L.M.S., CERQUEIRA, R., MELO, F.R., RODRIGUES, F.H.G. and SILVA, V.M., 2008. Mamíferos ameaçados de extinção no Brasil. In: A.B.M. MACHADO, G.M. DRUMMOND and A.P. PAGLIA, eds. Livro vermelho da fauna brasileira ameaçada de extinção. 1st ed. Brasília: Ministério do Meio Ambiente; Belo Horizonte: Fundação Biodiversitas, pp. 681-702.

CIMARDI, A.V., 1996. Mamíferos de Santa Catarina. Florianópolis: Fundação de Amparo à Tecnologia e Meio Ambiente. 302 p.

CONVENTION ON INTERNATIONAL TRADE IN ENDANGERED SPECIES OF WILD FAUNA AND FLORA - CITES [viewed 3 May 2013]. CITES species database [online]. Geneva: CITES; 2012. Available from: http://www.cites.org/

CRAWSHAW, P.G., 1995. Comparative ecology of ocelots (Felis pardalis) and jaguars (Panthera onca) in a protected subtropical forest in Brazil and Argentina. Gainesville: University of Florida. $\mathrm{PhD}$ Thesis.

DEFLER, T.R., 1986. A bush dog (Speothos venaticus) pack in the eastern llanos of Colombia. Journal of Mammalogy, vol. 67, no. 2, pp. 421-422. http://dx.doi.org/10.2307/1380903.

DEMATTEO, K.E., 2008. Using a survey of carnivore conservationists to gain new insight into the ecology and conservation status of the bush dog. Canid News, no. 11, pp. 1-8.

DEMATTEO, K.E. and KOCHANNY, C.O., 2004. Determining an effective and safe radio-tracking collar for bush dogs (Speothos venaticus). Canid News, vol. 7, no. 7, pp. 1-5.

DEMATTEO, K.E. and LOISELLE, B.A., 2008. New data on the status and distribution of the bush dog (Speothos venaticus): Evaluating its quality of protection and directing research efforts. Biological Conservation, vol. 141, no. 10, pp. 2494-2505. http:// dx.doi.org/10.1016/j.biocon.2008.07.010. 
DEMATTEO, K.E., CARRILlO, O., ZUERCHER, G.L., RAMIREZ, S., SMITH, K. and PORTON, I.J., 2004. A technique for attracting bush dogs (Speothos venaticus) in the wild. Canid News, vol. 6, no. 7, pp. 2-11.

EISENBERG, J.F., 1989. Mammals of the neotropics. Chicago: University of Chicago Press. 449 p.

EMMONS, L.H. and FEER, F., 1997. Neotropical rainforest mammals: a field guide. Chicago: University of Chicago Press.

FONTANA, C.S., BENCKE, G.A. and REIS, R.E., 2003. Livro vermelho da fauna ameaçada do Rio Grande do Sul. Porto Alegre: Pontifícia Universidade Católica do Rio Grande do Sul.

FUSCO, R. and INGBERMAN, B., 2012. Records of the bush dog Speothos venaticus in a continuous remnant of coastal Atlantic Forest in southern Brazil. Oryx, vol. 47, no. 1, pp. 105-108. http:// dx.doi.org/10.1017/S003060531200052X.

INTERNATIONAL UNION FOR CONSERVATION OF NATURE - IUCN, 2012a. IUCN Red List Categories and Criteria: Version 3.1. 2nd ed. Cambridge: IUCN. 32 p.

INTERNATIONAL UNION FOR CONSERVATION OF NATURE - IUCN, 2012b [viewed 10 August 2014]. Red List of Threatened Species version 2012.2 [online]. Cambridge: IUCN. Available from: http://www.iucnlist.org

LIMA, E. S., DEMATTEO, K.E., JORGE, R.S.P., JORGE, M.L.S.P., DALPONTE, J.C., LIMA, H.S. and KLORFINE, S.A., 2012. First telemetry study of bush dogs: home range, activity and habitat selection. Wildlife Research, vol. 39, no. 6, pp. 512-519.

MACHADO, A.B.M., MARTINS, C.S. and DRUMMOND, G.M., 2005. Lista da fauna brasileira ameaçada de extinção: incluindo as espécies quase ameaçadas e deficientes em dados. Belo Horizonte: Fundação Biodiversitas.

MANGINI, P.R., BRAGA, F.G., BILSKI, D. and MORO-RIOS, R.F., 2009. Plano de conservação para cachorro-vinagre (Speothos venaticus). In: G.P. VIDOLIN, M.G.P. TOSSULINO and M.M. BRITTO, eds. Planos de conservação para espécies de mamíferos ameaçados. Curitiba: Instituto Ambiental do Paraná, pp. 96-104.

MARGARIDO, T.C.C., 1995. Mamíferos ameaçados de extinção no Paraná. In: M.P.G. TOSSULINO, ed. Lista vermelha de animais ameaçados de extinção no Estado do Paraná. Curitiba: Instituto Ambiental do Paraná. 175 p.

MARGARIDO, T.C.C. and BRAGA, F.G., 2004. Mamíferos ameaçados de extinção do Estado do Paraná. In: S.B. MIKICH and R.S. BÉRNILS, eds. Livro vermelho da fauna ameaçada de Extinção do Estado do Paraná. Curitiba: Mater Natura/SEMA.

MICHALSKI, F., 2010. The bush dog Speothos venaticus and short-eared dog Atelocynus microtis in a fragmented landscape in southern Amazonia. Oryx, vol. 44, no. 2, pp. 300-303. http:// dx.doi.org/10.1017/S0030605309990871.

OLIVEIRA, T.G., 2009. Distribution, habitat utilization and conservation of the Vulnerable bush dog Speothos venaticus in northern Brazil. Oryx, vol. 43, no. 2, pp. 247-253. http://dx.doi. org/10.1017/S0030605307002347.
PERES, C.A., 1991. Observations on hunting by small-eared (Atelocynus microtis) and bush dogs (Speothos venaticus) in central-western Amazonia. Mammalia, no. 5, pp. 635-639.

REDFORD, K.H. and EISENBERG, J.F., 1992. Mammals of the neotropics. 2nd ed. Chicago: University of Chicago Press. $430 \mathrm{p}$.

REDFORD, K.H. and EISENBERG, J.F., 1999. Mammals of the neotropics. 3rd ed. Chicago: University of Chicago Press. 609 p.

RODRIGUES, F.H.G., MEDRI, I.M., TOMAS, W.T. and MOURÃO, G.M., 2002. Revisão do conhecimento sobre a ocorrência e distribuição de mamíferos do Pantanal. Corumbá: Embrapa. 41 p. Documentos, no. 38.

SÃO PAULO. Secretaria do Meio Ambiente - SMA, Governo do Estado de São Paulo, 1998. Fauna ameaçada no Estado de São Paulo. São Paulo: SMA/CED.

SHELDON, J.W. ,1992. Wild dogs: the natural history of the nondomestic Canidae. San Diego: Academic Press.

SILVA-JÚNIOR, J.S. and SOARES, M.C.P., 1999. An unexpected new record for the bush dog, Speothos venaticus Lund, 1842, in the Brazilian Amazonia (Carnivora, Canidae). Publicações Avulsas do Instituto Pau Brasil, no. 2, pp. 7-11.

SILVEIRA, L.A., JACOMO, A.T.A., RODRIGUES, F.H.G. and DINIZ-FILHO, J.A.F., 1998. Bush dogs (Speothos venaticus) in Emas National Park, central Brazil. Mammalia, no. 62, pp. 446-449.

STRAHL, S.D., SILVA, J.L. and GOLDSTEIN, I.R., 1992. The bush dog Speothos venaticus in Venezuela. Mammalia, no. 56, pp. 9-13.

TERIBELE, R., CONCONE, H.V.B., GODOY, M.N., BIANCHI, R.C., SANTOS, J.C.C., MAURO, R.A., XAVIER-FILHO, N.L. and MELLO, A.V., 2012. New records for bush dog in Mato Grosso do Sul, Brazil. Canid News, no. 15, pp. 1-4.

VELOSO, H.P., RANGEL-FILHO, A.L.R. and LIMA, J.C.A., 1991. Classificação da vegetação brasileira adaptada a um sistema universal. Rio de Janeiro: IBGE, pp. 1-124.

VIEIRA, C., 1946. Carnívoros do Estado de São Paulo. Arquivos de Zoologia, no. 5, pp. 135-175.

WILSON, D.E. and REEDER, D.M., 2005. Mammal Species of the World: a taxonomic and geographic reference. Baltimore: The Johns Hopkins University Press.

ZANON, C.M.V., GEALH, A.M. and BRUSAMARELLO, L.C.C., 2003. Último relato conhecido de cachorro-do-mato-vinagre (Speothos venaticus) na região dos Campos Gerais, Paraná, Brasil. In: Anais do II Congresso Brasileiro de Mastozoologia, 2003, Belo Horizonte, MG. Porto Alegre: Sociedade Brasileira de Mastozoologia, pp. 34.

ZUERCHER, G.L., GIPSON, P.S. and CARRILLO, O., 2005. Diet and habitat associations of bush dogs Speothos venaticus in the Interior Atlantic Forest of eastern Paraguay. Oryx, vol. 39, no. 1, pp. 86-89. http://dx.doi.org/10.1017/S0030605305000153.

ZUERCHER, G.L., SWARNER, M., SILVEIRA, L. and CARILLO, O., 2004. Bush dog Speothos venaticus (Lund, 1842). In: C. SILLERO-ZUBIRI, M. HOFFMANN and D.W. MACDONALD, eds. Canids: foxes, wolves, jackals and dogs. Status survey and conservation action plan. Cambridge: IUCN, pp. 76-80. 


\section{Erratum}

In the article "A review of bush dog Speothos venaticus (Lund, 1842) (Carnivora, Canidae) occurrences in Paraná state, subtropical Brazil”, DOI http://dx.doi.org/10.1590/1519-6984.20914, published in Brazilian Journal of Biology, vol. 76 , no. 2 , pp. 444-449, in the identification of the institutions of the authors on page 444 :

where it reads:

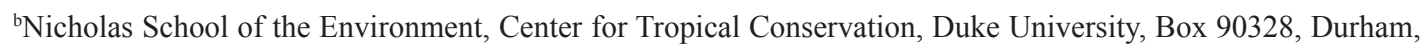
NC 27708, England

it should be read:

${ }^{\mathrm{b} N i c h o l a s ~ S c h o o l ~ o f ~ t h e ~ E n v i r o n m e n t, ~ C e n t e r ~ f o r ~ T r o p i c a l ~ C o n s e r v a t i o n, ~ D u k e ~ U n i v e r s i t y, ~ B o x ~ 90328, ~ D u r h a m, ~}$ NC 27708, United States 